\title{
Social Inequality and County-Level Correlates of State Prison Releases and Releases from Community Supervision
}

\author{
Ronald Helms (Corresponding author) \\ Department of Sociology, Western Washington University \\ Bellingham, WA 98225-9081, USA \\ Tel: 1-360-650-7927Ｅ-mail: Ronald.Helms@wwu.edu
}

\author{
S. E. Costanza \\ University of South Alabama \\ Mobile, AL 36688, USA \\ Ricky S. Gutierrez \\ California State University, Sacramento \\ 6000 J. St. Sacramento, CA 95819-6085, USA
}

Received: July 30, 2015 Accepted: August 20, 2015 Published: March 7, 2016

doi:10.5296/ijssr.v4i1.8905 URL: http://dx.doi.org/10.5296/ijssr.v4i1.8905

\begin{abstract}
Prisoner reentry is an important contemporary policy concern as many ex-convicts reenter communities uneducated and unprepared to compete in local labor markets. This study uses data from the 2003 National Corrections Reporting Program (NCRP) for the states of California, Illinois and Washington to examine contextual correlates of reentry patterns. The analyses reveal systematic correlates of releases from both incarceration and community supervision that highlight a diverse array of difficulties for offenders returning to their home community. The results of this study underscore the often-difficult transitions facing reentering offenders and support policy implications for those who oversee reentry processes.
\end{abstract}


Keywords: reentry, offender, punishment, probation, parole

\section{Introduction}

The literature on reentry has raised questions about conditions that interfere with successful reentry and these get to the heart of a key issue in public policy at a time when public resources are in short supply and pressure has increased to turn the tide on mass incarceration. The punishment literature provides a variety of clues that can assist in formulating actionable remedies. For example, there is evidence that variation in structured environments and ascribed characteristics of offenders correlate with punishment severity (Hogg 2011; Helms and Costanza 2010; Paternoster, Brame, Bacon, \& Ditchfield, 2004; Helms 2009; Helms \& Jacobs, 2002; Hallett, 2002; Feld, 1991). These and other studies offer conclusive evidence that more severe sanctions are leveled at offenders from disorganized, minority and economically disadvantaged environments (Note 1). The literature focusing on offenders has emphasized that a majority of released offenders return to high crime areas, a fact that may contribute to their becoming reacquainted with crime and the criminal justice system.

With regard to neighborhood settings, several important studies provide theoretical perspective regarding the ways structural environments shape offender experiences upon returning to the community (Kilburn, Costanza, Frailing \& Diaz 2014; Clear 2005; Petersilia 2003; Travis 2005). These give leverage to other research that documents sources of offender recidivism (Hipp, Petersilia \& Turner 2010; Kubrin, Squires \& Stewart 2007). What is not as well-documented is a correlational approach that observes the patterned way in which offenders are released into these structured environments. This study focuses on what is for many offenders the interim experience between episodes of correctional control (Kubrin \& Stewart 2006), by analyzing contextual correlates of prison and community supervision releases.

Released offenders commonly return to high-risk economically distressed environments, where they often confront a gauntlet of poorly functioning institutions such as churches, families, and schools along with limited political representation and scarce opportunities to become gainfully employed. Likewise they face a structured environment that is often inhospitable to their arrival in the form of housing difficulties, racially divided communities, concentrated poverty and other features contributing to social stress (Kilburn, et al. 2014; Clear 2007, Petersilia 2003, Travis 2005). Returning offenders are also routinely the targets of enhanced suspicion and surveillance by agents of social control, whose pro-active efforts contribute to a strong likelihood that released offenders will be caught up in police operations at the local level and eventually returned to prison.

Each year an estimated 700,000 previously incarcerated offenders return to their home communities (Lynch \& Sabol 2007). Both community supervision and imprisonment have been enhanced over the course of several decades through intermediate sanctioning efforts and the "get-tough" philosophy that has dominated the political discourse on punishment. For those coming back to the community from prison stays, the totalizing qualities (Goffman, 1961) of penal institutions take a substantial toll on the psyche. 
Early findings on recidivism (Martinson, 1974) helped steer policy makers towards more punitive and retributive goals for the prison system. Rehabilitation remains a relevant subject in American debates about crime control (Jonson \& Cullen, 2013; Jans, 2002) but the political discourse has often treated rehabilitation as, at best, an ancillary consideration relative to the regime focus on punitive justice. Indeed, during the last four decades, crime control strategies have been a double-edged sword, stifling efforts to improve prison programs and diminishing the integrity of reentry policies (Kilburn \& Costanza, 2009; Johnson-Listwan, Cullen, \& Latessa, 2006). There have been some documented successes among programs seeking to rehabilitate offenders (Grommon, Davidson, \& Bynum, 2013). Such programs, however, remain narrowly focused on addressing individual shortcomings thought to affect recidivism. All else being equal, these programs operate on the expectation that idiosyncratic adjustments to targeted offenders will result in life-altering changes. But unfortunately, the ipso facto ideal (wherein the reprogrammed offender steps out of prison and becomes an upright citizen) doesn't always hold and so treatment effects too often fall short in practice.

Assessing the efficacy of programs to facilitate prisoner reentry is an important area of contemporary concern for policy makers (Schwarzfeld, Weiss, Plotkin, \& Draper, 2008). But emphasizing individualized justice without attention to agent-structure considerations is myopic. Most contemporary research suggests that two-thirds of offenders will be rearrested within 3 years of their release (Mears, Wang, Hay, \& Bales, 2008; Decker, 2007). Many of these arrests will terminate with a new prison sentence. There is an apparent preparation gap that leaves offenders at risk of failure and communities at risk of new crimes.

Analysis focused on the receiving community environments where offenders will be returning upon release from correctional control can facilitate both better targeted prison programming and improvements in administration of community supervision. In the analysis that follows, we emphasize contextual indicators and highlight the variable landscapes to which offenders are being released, both as a cautionary tale and as a motivation to renewed consideration of the social and political foundations of criminal recidivism.

\section{Literature Review}

The purported goal of both prison and community supervision is to address illegal behavior by correcting perceived deficits within the offender. In this sense both types of criminal sanctioning nominally strive toward rehabilitation. Cullen \& Gendreau (2000) argue that effective rehabilitation programs should: a) target known predictors of crime and recidivism; b) develop interventions that are designed to address negative behavior patterns; c) focus treatment on higher risk offenders; and, d) make efforts to match treatment service and the learning style to offenders. The overwhelming majority of commissioned reports take an optimistic approach, focusing attention on "what works." However, these reports provide almost no insight regarding the environmental terrain offenders will be returning to upon completion of correctional programming. 


\section{2a. Vocational and Educational Programming}

Most research on rehabilitation has addressed possible correlations between educational programs and anticipated reductions in recidivism (Jancic, 1998; Nuttall, Hollmen, \& Staley, 2003; Gaes, 2008; Messner \& Rosenfeld, 2009). Zoukis (2012) states: "As compared to the general population, prisoners are an under-educated class coming from a culture of poverty, with few skills for handling everyday tasks, and little or no experience in a trade or career." In support of this statement he draws attention to a New Mexico study (Gaes, 2008) showing that $10 \%$ of their offenders arrived with educational skills at or below the third-grade level, $32 \%$ had skills at or below the sixth-grade level in reading and math, only $50 \%$ of the offenders could claim a high-school diploma, and less than 20 offenders in the cohort $(.003 \%)$ had some college-level education. Given these kinds of results, it should come as no surprise that programs focusing on remedial educational attainment are a typical and much needed area of programming within the US prison system.

The prison literature includes a substantial body of program evaluation research addressing educational programming (Tewskbury, Ericson, \& Taylor, 2000; Aos, Cecil, Drapkin, \& MacKenzie, 2000; Kelso, 2000; Miller \& Drake, 2000; MacKenzie \& Hickman, 2000; Gallaher \& MacKenzie, 2000; Messemer, 2003; Chappell, 2004; Wells, 2004; Miller \& Drake, 2006; Wilson, Boufard, \& McCarthy, 2006). Most of these reports, in one way or another, and as noted by Vacca (2004) subscribe to the following formula for success: "Literacy skills in learner-centered programs with meaningful contexts that recognize the different learning styles, cultural backgrounds and learning needs of inmates are important to program success and inmate participation." (Vacca, 2004, p. 297). Many researchers also emphasize that correctional efforts should support the inculcation of useful skills to assist with transition away from crime (Gomez, 2008). Unfortunately, supervision across the spectrum of correctional controls usually places a heavy emphasis on accountability and compliance with terms and conditions so that educational and vocational aspects become a secondary concern as a practical matter.

Some prisons offer a regimen of vocational skills development opportunities. A literature has sought to evaluate programmatic effects (Haynes 1996; Saylor \& Gaes, 1997, 2001; Wilson, Gallagher, \& Mackenzie, 2000; Boufard, MacKenzie, \& Hickman, 2000). Critiques of vocational programming call into question the match between skills taught and the labor market conditions faced by offenders upon release (Gerber \& Fritsch, 1995; Visher, Winterfield, \& Coggeshall, 2005). One wonders for example how much utility there is in learning the skills of a brick mason or a janitor, raising and slaughtering factory-farmed animals or sitting at a machine sewing jeans or stamping out license plates for prison industries. Farley, Murphy \& Bedford (2012, p. 1) note that "almost universally, prisoners are not permitted any access to the internet, and ICTs [information and communication technologies] because they often pose an unacceptable security risk." And so the rapidly digitizing globalized economy (evidence on global dimensions of the economy and digitized security systems can be seen in Helms, Costanza, \& Johnson 2012; Helms \& Costanza 2014), which affect nearly all labor market participants, present additional challenges for the typical homeward bound offender. 
2b. Medical/Mental Health Treatment and Other Types of Programs

Medical/mental health treatment programs offered in prison are known to affect the reentry process. A body of research documents generally favorable effects of cognitive and therapeutic programming (Farkas, 2000; Rohde, Jorgensen, Seeley and Mace, 2004; Vannoy \& Hoyt, 2004; Sayre, 2006, Callan \& Gardner, 2007; Lambert, Hogan, Barton, \& Stephenson, 2007; Nee \& Farman, 2007; DeHart, 2010; Polaschek, Bell, Calvert, \& Takarangi, 2010). The utility of programs targeting drug and alcohol addiction/recovery processes is well-documented (Melnick, de Leon, Thomas, Kressel, \& Wexler, 2001; Lucente, Fals-Stewart, Richards, \& Goscha, 2001; Stohr, Hemmens, Shapiro, Chambers, \& Kelley, 2004; Mitchell \& Harrell, 2006; McSweeney, Stevens, Hunt, \& Turnbull, 2007; De Leon \& Wexler, 2009). In addition to the prison programs, offenders serving community sentences for drug or alcohol related crimes are generally required to participate in substance abuse programing.

\section{2c. Limitations of Correctional Programming Research}

Most correctional programming research is limited to studies of people in prison as opposed to more common probationers. In a meta-analysis of 32 research efforts, Seiter \& Kadela (2003, p. 380) found that effective strategies aimed at reducing recidivism include work release programs (which assist with job readiness), drug treatment programs (that curb drug use), and interventions that address drug-related crimes and parole violations associated with illicit drug use and possession. Their research suggests that reentry programs can be problematic when the social environment of those being released is altered, when there is community instability, or when the availability of programs is constrained (Note 2).

Empirical research addressing best practices argues that targeted educational, vocational, and therapeutic initiatives can effectively change some offenders and reduce their likelihood of engaging in new crimes. Unfortunately, while such statements are likely true, they do not acknowledge a different truth, that offenders are quite typically released into environments that are highly conducive to recidivism. Correctional program evaluation research exemplifies a pragmatic approach to addressing the reentry process, as can be seen by reviewing notable studies in this expansive field. Mills (2004) provides a normative overview, arguing that when seeking to ameliorate the recidivism dilemma, a wide range of community players should be involved in dialogue "about the impact on their communities that the flood of reentering ex-offenders is having; and about the resources that are lost to their communities as these people flow in and out of prisons and in and out of their families' homes" (p. 183).

Recent correctional policy has focused more on punishment than on rehabilitation, concentrating more on isolating criminals rather than addressing their criminogenic needs. Although the array of research reports is laudable (and we strongly encourage continued evaluation and refinement of these program areas), none fully addresses the fact that reentry drops inmates into a social terrain that is not well situated to accommodate them upon their release. Although this is a quite plausible summation of the situation, the empirical literature has yet to fully reflect upon this critical aspect of the reentry problem. 
The research that follows provides evidence on release environments, focusing on environmental correlates of prison release patterns and also patterns of releases from community supervision across three states, California, Washington, and Illinois (Note 3). We focus on releases from state incarceration, and also releases from parole and probation, for offenders processed in 2003. This focus should provide insight into a range of risks and opportunities facing offenders, as well as correctional officials and state legislators as managers of correctional resources. The results of this study offer a basis for rethinking reentry policies in order to better prepare inmates for their release and adapt programming so that non-criminal alternatives become more readily available to those who are being released. Since the focus of this research emphasizes an array of community correlates the following section highlights a range of alternative hypotheses.

\section{Hypotheses and Indicators}

Economic and social stress indicators have figured strongly in explanations for crime and punishment variation. Indicators such as economic and racial inequality, joblessness, variation in household incomes, and conservative political ideology among others have all been shown to correlate with heightened punishments. We expect that similar factors will correlate with incarceration releases, but community supervision releases may be differentially influenced by these same factors. To assess these insights, correctional release data were merged with data from the US Census and other sources to produce a rich data set for analysis.

\section{3a. Concentrated Disadvantage}

Concentrated disadvantage (Wilson 1987; Land, McCall, \& Cohen 1990; Parker, McCall, \& Land, 1999) has been theorized and empirically assessed in many studies of crime and punishment and so we follow established precedent. We expect to observe a positive association between a combined indicator of concentrated disadvantage and the prison release variable since we expect offenders to be released into the most disadvantaged areas. But we expect offenders to be less successful in serving community sentences in these areas and so the coefficient sign should be negative for our second analysis.

\section{3b. Unemployment Effects}

A high unemployment rate undoubtedly limits labor opportunities for reentering felons and reduces the likelihood of success for offenders under community correctional control. Under circumstances of high unemployment, we expect that courts would typically opt for more formal controls over high-risk populations (Greenberg, 1975; Chiricos \& Delone 1992). In keeping with this expectation, Holzer, Raphael \& Stoll (2004) administered an employer survey from four major U.S. cities and found that $19.5 \%$ of employers reportedly would not hire ex-offenders while an additional $42.1 \%$ said they probably would not hire ex-offenders. These findings paint a bleak job picture for ex-offenders. We therefore expect to observe a positive relationship with the prison release indicator (reflecting earlier decisions to impose restrictive controls), but we expect to observe a negative association with releases from 
community supervision since offenders should be less successful in environments characterized by greater labor market difficulties.

\section{3c. Black Median Incomes}

In a highly mobile materialist culture, income is essential to meeting basic needs in the community. We attempt to capture the essence of this requirement with an indicator for Black median incomes. Blacks are overrepresented in prison admission data and are disproportionately disadvantaged in most communities. Blacks typically draw lower incomes and resemble the economic profile for the least well off at the community level and so the indicator serves as a proxy for reduced median incomes for all groups. We expect to observe a negative association between incarceration releases and Black median incomes since jurisdictions with higher incomes most likely would have fewer members returning from incarceration. However, with regard to community-supervised releases, we expect felons to fare better due to community level opportunities that increase the likelihood of successfully serving their sentences. In short, we expect to observe a positive association between Black median incomes and the rate of releases from community supervision.

\section{3d. Manufacturing Employment Changes}

Manufacturing historically has allowed minorities and the poor to participate successfully in the labor market and rise into the middle class without onerous educational requirements (Myers \& Sabol, 1987). Manufacturing employment changes reflect long-term trends. Where manufacturing jobs steeply declined over many years this shift in labor opportunities probably contributed to heightened risks of crime and imprisonment. One consequence is that prison release rates should also be associated with these same shifts in manufacturing employment opportunities. Having said that, while much of the US experienced losses in manufacturing employment that trend has not been universal. Some areas were recent beneficiaries of new manufacturing investments and job growth. We expect that where manufacturing jobs increased as a percentage of the overall market for labor, these opportunities to engage in productive work likely reduced the risk of imprisonment. Areas with growing labor opportunities should be more hospitable to community supervision. And for offenders supervised locally, the same conditions should assist with successful completion of community-based sentences. And so, we expect to observe an inverse relationship between an indicator of manufacturing change and releases from prison. But we expect to observe a positive association between this same manufacturing indicator and releases from community supervision.

\section{3e. Educated Local Populations and Reentry Processes}

There is evidence supporting links between education and labor market returns (Day \& Neuberger, 2002) and so educational influences should not be overlooked. A key assumption for correctional administrators is that at the individual offender level educational attainment is a likely contributor to successful reentry since education should make offenders more competitive in the labor market. But the receiving community's education level should also influence the likelihood of successful reentry. We expect that older and more educated 
populations will be less directly involved in labor market competition with criminal defendants and should be associated with better prospects for reentry but a lower rate of prison releases. On the other hand, educated local populations that are somewhat younger will likely experience more direct labor market competition with offenders, and so we expect that in these jurisdictions there will be more difficulties with reentry. As with other conceptual controls we expect that effects will differ across the two analyses, reflecting distinct processes linking patterns of incarceration and subsequent release, on one hand, and successful community supervision, on the other hand.

\section{3f. Drug Offending and Reentry Patterns}

Drug offending has been the focus of political discourse throughout the past 40 years, and has been suspected as a key source of growing prison populations (Helms \& Costanza, 2010) and other social control processes (Helms \& Costanza, 2009). We proxy for the level of drug offending with an indicator of police drug arrests. Drug arrests are an indicator of police emphasis and prioritization at the community level and so it should be a factor affecting success/failure for supervised offenders. Where drug arrests are greatest, we expect prison releases will be enhanced, reflecting sources of previous patterns of incarceration. We also expect a greater rate of failure among community-supervised offenders in these same jurisdictions where drug law enforcement is strongly emphasized. In sum, we expect to observe a positive association between the drug arrest indicator and prison releases but a negative association between the arrest indicator and the rate of releases from community supervision in the analyses that follow.

\section{3g. Conservative Political Support}

We include an indicator representing conservative political support in the community since the most conservative communities have been shown to rely on prison to a greater extent than their more liberal counterparts (Jacobs \& Helms 1996; Helms \& Jacobs 2002; Helms 2009; Helms \& Costanza 2009). We expect to observe this relationship since conservative candidates have consistently included in their campaign platforms endorsements for enhanced punishments. Where communities most strongly supported political candidates from the Republican Party, the party most closely identified with conservative appeals for enhanced law enforcement and punishments, we expect to observe greater reliance on imprisonment. Consequently we should observe more releases to these same environments. But since the focus is on punitive enforcement we expect a reduced rate of releases from community supervision in these law and order environments where failures are more likely to be met with revocation and remand to a state facility.

Finally, all states by 2003 had substantially revised their sentencing statutes and many, perhaps most, realigned their statutes to a more strictly determinate sentencing regime. California, by many accounts, went the furthest with its three strikes statutes. These were part of a much more comprehensive set of reforms involving truth in sentencing and generally punitive punishment practices. State level dummies allow an operational means of statistically holding constant all systematic but otherwise unmeasured state-level influences. Therefore, we include dummy indicators for Washington and Illinois, with California serving 
as the reference or omitted category. Using this operationalization, we expect to observe that Washington and Illinois exhibited reduced releases when compared with California, net of other factors affecting releases.

\section{Data and Methods}

We proceed logically with the merging and analysis of several databases to assess the above-mentioned processes. Data on incarceration releases and also community supervision releases were merged with data from the 2000 U.S. census, $2000 \mathrm{UCR}$, and data by Gallup-Black (2005) to provide a rich analysis of the contextual environments offenders are returned to upon having served a period of incarceration or a community supervised sanction.

Primary data on offenders for this study were acquired from the ICPSR and were originally compiled by the U.S. Department of Justice (2003) based on annual reporting from participating states' departments of corrections. Two data sets form the basis for descriptive statistics on prison releases and populations released from community supervision and are used to develop dependent variables for our research. The dependent variables in this section of the report are the per-capita rates of prison releases and the rate of releases from community supervision. Initial analyses of the rates showed that both indicators were positively skewed and so both were logged.

\section{4a. Preliminary Analysis of Descriptive Data and Bivariate Correlations}

Table 1 provides descriptive information for all of the variables used in this analysis (mean, standard deviation, largest and smallest values, number of cases).

Table 1. Descriptive statistics

\begin{tabular}{|c|c|c|c|c|c|}
\hline & $\mathrm{N}$ & Minimum & Maximum & Mean & Std. Deviation \\
\hline Nat Log of Prison Releases per 10,000 Pop. & 199 & .73 & 7.18 & 3.0584 & .72400 \\
\hline Nat Log of Community Releases per 10,000 Pop. & 58 & .00 & 5.54 & 2.2107 & 1.01356 \\
\hline Index of Concentrated Disadvantage & 199 & -1.55690 & 2.05350 & -.1742275 & .72350143 \\
\hline Black median income & 199 & .00 & 102264.00 & 31659.7563 & 19127.21127 \\
\hline \% Change in Manuf., 1980 - 1990 & 199 & -13.30 & 6.60 & -2.4603 & 3.34901 \\
\hline$\%$ Unemployment & 199 & 1.80 & 23.40 & 6.0568 & 2.95888 \\
\hline \% Younger Pop with H.S. Degree & 199 & 54.3727 & 91.8422 & 76.417620 & 6.8851777 \\
\hline \% Older Pop with H.S. Degree & 199 & 45.6924 & 90.3009 & 69.125171 & 8.8207885 \\
\hline Rt. of Drug Arrests per 10,000 & 199 & .00 & 131.38 & 25.9232 & 31.29402 \\
\hline \% Republican Votes 2000 & 199 & .161 & .739 & .52548 & .096083 \\
\hline Nat Log of Total Population & 199 & 7.10 & 16.07 & 10.9312 & 1.60473 \\
\hline D. Washington & 199 & .00 & 1.00 & .1960 & .39795 \\
\hline D. Illinois & 199 & .00 & 1.00 & .5126 & .50110 \\
\hline D. California & 199 & .00 & 1.00 & .2915 & .45558 \\
\hline
\end{tabular}


Preliminary analysis of the data showed strong correlations among several of the independent variables included in the study. Evaluation of zero-order relationships showed preliminary evidence that collinearity might be a problem in subsequent analyses. . When present, collinearity can undermine the accuracy of regression estimates.

A principal components analysis allowed us to statistically evaluate the degree of overlap in the regression space and to produce an indicator that incorporates information from all of the respective indicators sharing the overlapping space. Several indicators exhibited strong correlations (poverty, single-parent households, percent Black population, and a measure of income inequality, the Gini index, computed on household incomes). Using un-rotated principle components methods, these were used to develop a combined indicator of concentrated disadvantage. Zero-order relationships among predictors at this point are modest, suggesting that collinearity concerns have been addressed sufficiently.

We turn our attention now to a statistically based examination of contextual correlates of prison releases and releases from community supervision. We proceed first with an explication of data and indicators and the logic for their inclusion in this study. We then follow with an analysis of regression results for the respective outcomes in this study.

\section{4b. Demographics of Those Admitted and Released from State Incarceration}

While this study focuses on those released from correctional facilities or from community supervision, we note in passing information on admitted prisoners in the three states to facilitate comparisons about respective trends in admissions and releases. While the overall prison admissions for 2003 for the three states was 168,482, California clearly was the largest incarcerator with a total of 120,233 admissions (71.4\% of the sample), while Illinois had 35,879 ( $21.3 \%$ of the sample), and Washington had 12,370 admissions ( $7.3 \%$ of the sample). With regard to releases from state prison, California again led the states with $120,762(73.9 \%$ of the sample) followed by Illinois with $35,007(21.4 \%$ of the sample) and Washington with 7,547 releases $(4.6 \%$ of the sample). We note that while release totals for California and Illinois very closely match admissions totals, Washington released substantially fewer offenders in 2003 than they admitted to state prison.

The demographic profile of released offenders somewhat resembles that of admitted offenders during the year. Most offenders admitted and released were male (over 90\%) and substantial percentages were minorities (46\% admissions; $28.5 \%$ of releases). Offenders across the three states on average exhibited a profile that is consistent with the literature on offenders. The racial minority populations across the three state systems also show noteworthy patterns since they are over represented when compared with their population percentages within the respective states. In California, for example, Black offenders were approximately $40 \%$ of the admitted population in 2003 but were only approximately $6.7 \%$ of the population. Blacks made up a small minority in both Washington (3.7\%) and Illinois $(14.9 \%)$ but a greater percentage of the newly admitted offenders (and released offenders as well since $9.2 \%$ of Washington offenders were Black; In Illinois, the comparable percentage was $21.9 \%$ ). Regarding minority offenders as a group, minorities were $46 \%$ of admissions in California, $21 \%$ in Illinois and $14 \%$ in Washington with $45 \%, 23 \%$, and $16 \%$ of releases, 
respectively. In sum, prison admissions and releases continue to reflect an overrepresentation of minority offenders when compared with respective state population profiles.

The prisoner age profile across the three states showed that the average age at the time of admission was 34 while the average age at release was 35 . The range in the release data was substantial, with the youngest offender being 15 and the oldest being 87. Having noted these extremes, the standard deviation for our sample of offenders was 9.7 implying that the vast majority of the sample was made up of young and middle aged adults.

Perhaps it comes as no surprise that the average educational attainment for those incarcerated in 2003 was quite low. Unfortunately, our data only allow us to make inferences about the current status of offenders based on the experiences in Washington and Illinois since California did not report educational attainment information on any of their admitted or released offenders, nor for inmates released from community supervision (probation and parole).

Washington and Illinois offender admissions were typically at an educational deficit. Among those admitted to prison in Washington, 94\% had no college level education whatsoever, and $48 \%$ had neither completed high school nor earned a GED. Similarly, 89\% of admitted Illinois inmates had no college education while $41 \%$ of the admitted offenders had failed to complete high school or earn a GED. Releases showed a similar pattern since the two states that reported information on educational attainment showed that a substantial majority of offenders returned from prison with continuing educational deficits (in Illinois $39.8 \%$ and in Washington $34.5 \%$ of offenders were released from prison with a high school degree or GED). In informal conversations with correctional officials and jail administrators in the state of Washington, we repeatedly were told that a disproportionate percentage of these offenders are functionally illiterate, meaning they are unable to complete basic tasks such as read a book or implement a written set of instructions, write down information or fill out a form, and complete basic math problems involving addition, subtraction, multiplication or division.

In today's technologically advanced workplaces, educational attainment is a key factor in labor competition and so it is not surprising to observe a pattern wherein those who are least competitive are most at risk of criminal offending and subsequent state incarceration. We can infer from the evidence reported here that today's prisons are dealing with a steady in-flow of offenders deficient in basic education. We can also assert with some confidence that the typical offender upon release operates with a continuing educational deficit. In short, the prisons in Washington and Illinois, perhaps despite significant expense and effort, have apparently not made substantial inroads in reducing the educational divide between felons and non-felons (Note 4). From this we infer that the situation today is characterized by substantial gaps in targeted education programs and offender attainment to improve the likelihood of successful post-incarceration reintegration into the community. We now turn to an analysis of results from our regression analysis. 


\section{Analysis of Prisoner Release Data}

\section{5a. Contextual Correlates of Release Patterns}

We note here that our focus is on contextual correlates of prison releases. We deliberately emphasize this to highlight a key issue in this research, which is to clarify the nature of problems facing prisoners upon being released back into their respective communities. One can logically emphasize the role of economic stress and other indicators of social inequality as determinants of prison admissions. Upon release, ex-prisoners face a range of contextual conditions that place them at varied risk of reoffending. Objective adverse environmental conditions such as high unemployment rates, a large impoverished population, skewed incomes, racially divided communities, and other factors may contribute to subjective adaptations on the part of released offenders with criminal implications. The contemporary literature on re-entry emphasizes the difficulty felons encounter as they attempt to re-integrate into the community (for example, see Travis, 2005). This set of challenges facing a released felon translates into practical considerations such as securing a living arrangement, getting a job or some other form of economic assistance, and in many instances linking up to community institutions such as medical and mental health, churches, local schools and labor markets. Our analysis (below) highlights localized structural variation across the receiving communities. Using this approach we seek to document links between social structure and patterns of offender releases. Isolating structural risk factors for recidivism should be of some benefit as we seek to articulate new policy directions to reduce the negative impacts associated with the reentry process.

The tabled results (see Table 2) show various community structural features that are closely associated with release patterns. The overall prediction model exhibits a strong ability to predict release patterns, as evidenced by the Pearson's $\mathrm{R}$ value of .700 . We can glean additional insight from analysis of individual regression coefficients. Much of what is evident in the table is not surprising since offenders appear to be released into socially disadvantaged settings, areas characterized by high poverty rates, economic inequality, minority populations, and broken households.

Offenders also appear to have been disproportionately released into highly populated areas. Additionally, politically conservative jurisdictions received offenders at heightened rates when compared with their more liberal counterparts. This is an expected result since these jurisdictions likely were admitting offenders at high rates for many years. Median incomes were not associated statistically with releases. The unemployment rate indicator also failed to achieve statistical significance in this or any of our (unreported) regression models. Offenders tended to be released from state incarceration into jurisdictions where manufacturing employment showed evidence of long term declines, unfortunately. Manufacturing jobs generally require less education and likely present opportunities for individuals most at risk of criminal activity to navigate their way without resorting to crime. But for this large sample of offenders, on average, they tended to be released into areas characterized by a limited range of manufacturing employment opportunities (Note 5). 


\section{Macrothink}

Table 2. OLS Regression Analysis of State Prison Release Rates for California, Illinois, and Washington Counties, $2003^{1}$

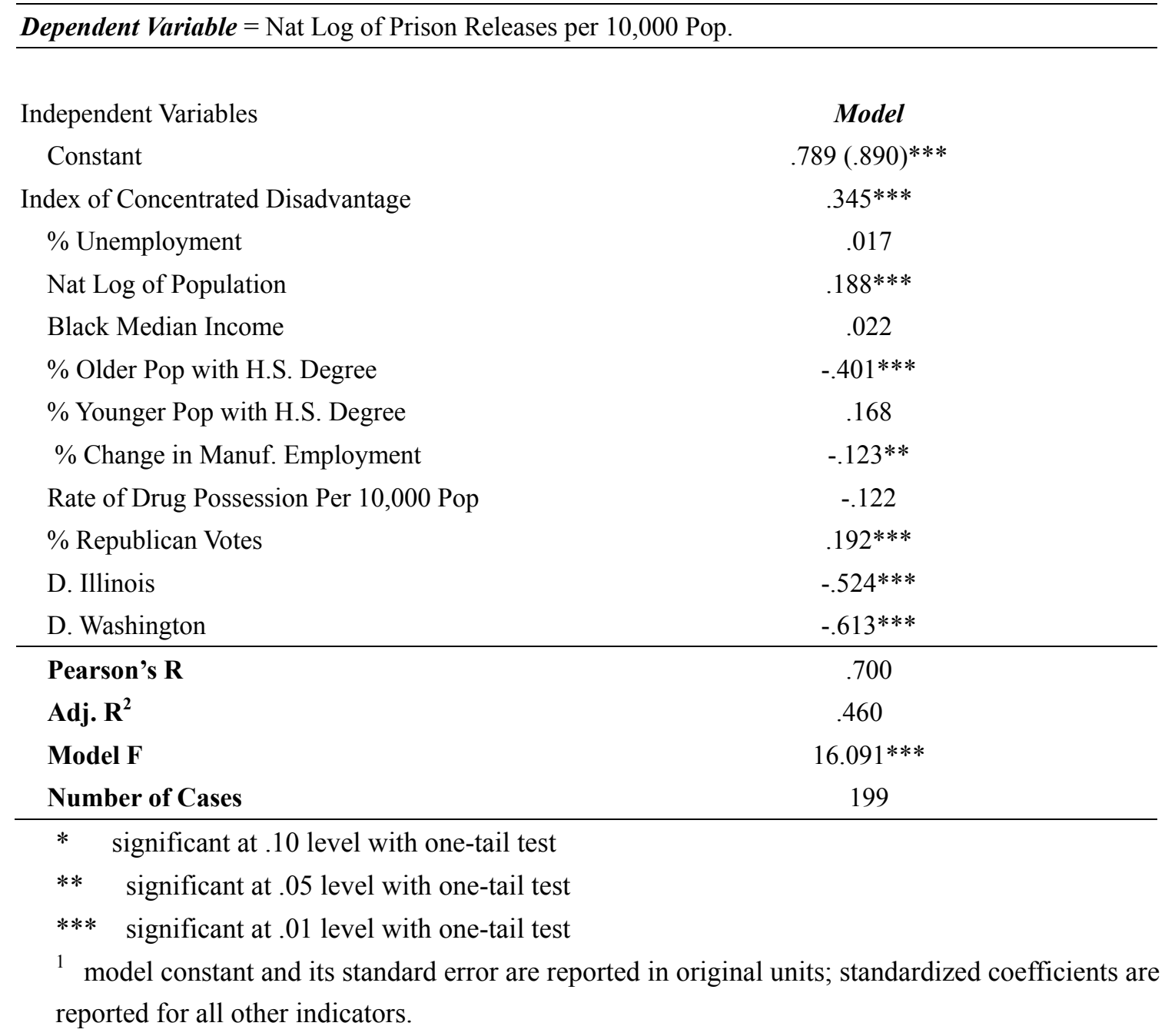

Regarding the educational status of the receiving population, areas with a larger educated older population did not receive as many released offenders as jurisdictions with smaller cohorts of older educated individuals. In other words, the analysis reveals that offenders were disproportionately coming home to jurisdictions where the older adult populations were characterized by low education completion rates. One possible explanation is that areas with larger cohorts of older high school educated people were less likely to send offenders to state prison in the first place. One potential downside to this pattern, however, is that for people facing discharge to their home community, there may be less sympathy for offenders who make poor choices involving new crimes.

Several hypotheses about patterns of reentry were not supported empirically. Offender releases were not significantly correlated with an indicator for younger high school educated populations. Also, the pattern of releases was not associated with an indicator of drug arrests.

Having noted these exceptions to our findings, we note the following: In sum, many of the releases place offenders in environments that present elevated risk factors for subsequent 
offender recidivism. Environments characterized by concentrated social and economic disadvantage and areas that have experienced losses in manufacturing employment have been recipients of the largest rates of released offenders. Offenders are also apparently being released to jurisdictions with larger populations, a factor that may foster recidivism since heavily populated areas present both opportunities for crime and reduced informal social control. In these environments, people are less likely to know one another and may be less likely to intervene in situations involving social conflict and crime (Sampson, Raudenbush \& Earls 1997). Finally, we note that both Washington and Illinois released offenders at significantly lower rates than did California, as evidenced from the significant negative coefficients on the respective state dummies.

\section{Analysis of Release Data for Offenders Released from Community Supervision}

\section{6a. Contextual Correlates of Offenders Released from Community Supervision}

The analysis presented in this section (Table 3) focuses on releases from supervision in California counties only since data are unavailable on community supervision releases for Illinois and Washington. Analysis of releases from community supervision logically fits with our previous discussion in that we focus on patterns of releases and risk factors associated with the observed patterns in the sample data. The overall model exhibits of moderate association with the dependent variable (Pearson's $\mathrm{R}$ value $=.560$ ) and using the prediction model allows us to reduce prediction errors by approximately $18.5 \%$.

Releases from community supervision across California counties were shown to be inversely and statistically significant inverse relationship with the concentrated disadvantage indicator. . Areas experiencing the greatest levels of disadvantage experienced the least success in releasing supervised offenders. As is evident in the tabled results, this result is present after statistically holding constant labor market and educational competition explanations. The inverse sign on the concentrated disadvantage coefficient is consistent with speculation that areas characterized by concentrated disadvantages present difficult challenges for offenders supervised in these communities.

Unemployment shows a negative association with community release rates so that greater community unemployment is correlated with reduced releases from community supervision. Offenders may be less able to compete in a slack labor market with a large reserve of unemployed workers. The results show a positive association between successful releases from community supervision and increased manufacturing employment. This is consistent with a hypothesis that in areas with stronger labor market opportunities that require less formal education (a condition typical of manufacturing processes) offenders should be more successful at completing community supervision successfully. We note, however, that the more general indicator of unemployment was negative indicating that a more generalized condition of employment stress was associated with fewer successful releases from local supervision. In combination, these suggest that variation in work opportunities are likely to present unique challenges for offenders who both during and after supervision must continue to navigate through the uncertain terrain of the labor market. 
Table 3. OLS Regression Analysis of State Community Supervision Release Rates for California Counties, $2003^{1}$

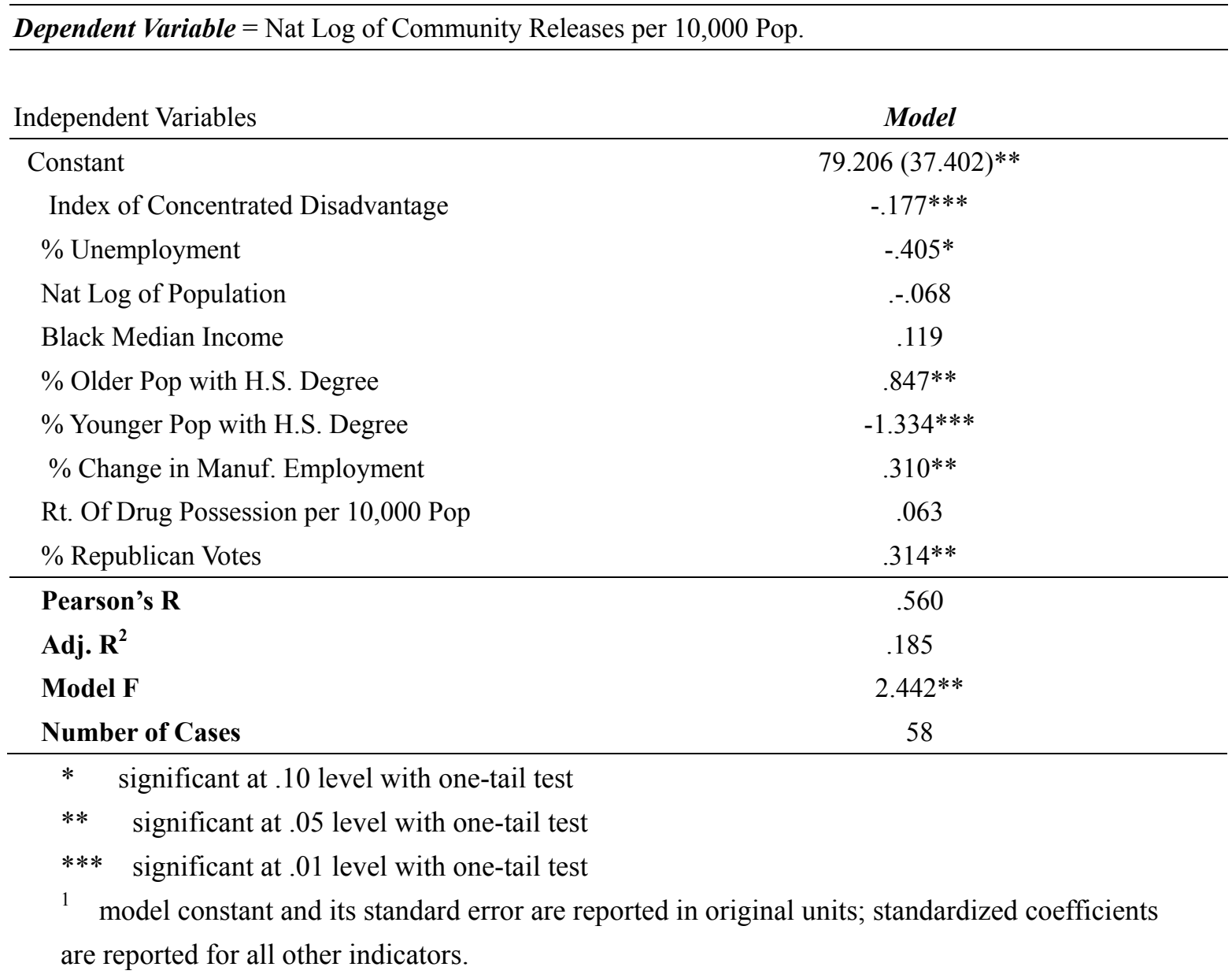

Indicators of high school completion rates were shown to have opposite signs for the older $(+)$ and younger (-) cohorts. In jurisdictions with an expanded cohort of older residents having completed high school degrees, offenders appear to have been released in greater numbers. But where there was a larger cohort of younger residents with high school degrees, offenders supervised in the community were less likely to be successfully released from supervision, as can be seen from the negative coefficient in the tabled results. Previously we emphasized a link between age cohorts and the labor market so that where offenders faced a larger population of high school educated residents they face a heightened risk of imprisonment. In the second regression table, the results are consistent with claims that offenders are more successful in gaining release from community supervision in those areas with an older high school educated cohort who might not be directly competing for labor market opportunities. But where there is a large cohort of younger high school educated residents, offenders appear less successful in completing their community-supervised sentences. We speculate that this may be a result of direct competition for limited labor opportunities and other factors related to a larger younger cohort of residents living in the community.

Population size, Black median incomes, and drug arrest rates were not significantly 
associated with release patterns. But offenders appear to have been released at greater rates from supervision in conservative law and order jurisdictions than in less conservative areas. One possibility is that these areas, expressing strong law and order priorities, may have sent more difficult cases up to state incarceration. One consequence of this tendency would be to have a larger local caseload of offenders with more manageable troubles and fewer serious probation and parole violations that would have resulted in revocation and remand to the state prison system. Put differently, the caseload would have had a greater likelihood of average successes than it otherwise might have. The data underlying this analysis do not allow any more detailed insight regarding this possibility. However, the sentencing research seems to support this speculation since many researchers have argued that judges and prosecutors share the underlying values of their constituents and are typically elected and/or must stand for re-election (Helms \& Jacobs, 2002; Helms, 2009; Helms \& Costanza, 2010). This ever-present reality may be expected to shape the courtroom calculus concerning offenders so that in the most politically conservative jurisdictions judges and prosecutors lean more strongly toward incarceration. If true, it would not be such a surprise to find that those offenders remaining in the community would be the least challenging cases. One implication of this argument is that we should expect to observe a positive association between an indicator of political law and order support and successful community supervision and releases into the community. The data presented in Table 2 would seem to support such a claim.

These results offer some insight from the state of California, the leading state in the area of corrections. The CDCR manages an expansive offender population and so their experience reflects extremes in all areas of corrections. They incarcerate and release offenders both from prison and from community supervision in volumes greater than the comparison states. The respective tables show estimated county correlates of prison releases, and (for California) releases from community supervision. The foregoing discussion emphasizes that diverse structural conditions that have been the focus of prison admissions research appear to also confront offenders upon being released from state incarceration. Finally, for offenders supervised locally, the results are consistent with claims that successes are not evenly distributed around the state of California and appear to be influenced by a variety of labor market and political factors. Such evidence may be expected to show some utility in assisting policy makers interested in targeting resources to maximize the benefits of community supervision strategies.

California is deeply immersed in the incarceration complex, and one result of mass incarceration is that the state also releases a large population of offenders annually. This has obvious ramifications for governmental budgets, but it also is undoubtedly having other effects as well. The social costs of imprisoning offenders is substantial in terms of broken families, loss of a parent or family member, disruption to what is very often an already fragile family economy, and individual labeling and social stigma (Edenfield 2002) that come with incarceration. All of these factors are socialized in numerous ways; the costs are widely shared, both directly by those closest to these processes and by others through restrictions in other areas of public budgeting such as schools, medical and mental health, poverty relief, 
and much else as well.

\section{Limitations in the Present Research}

The foregoing analysis has several limitations that reduce the generalizability of the study's findings. While the sample includes all county jurisdictions from three states, the experiences of these states may be somewhat unique when compared with other areas of the country. Also, the study uses a population size indicator but does not explicitly model urban/rural distinctions and so may overlook a key factor affecting punishment and release policies. The study focuses on counties as the unit of analysis, practical units for data collection since counties disseminate information on punishment processes and are the seat for localized punishment decision-making. Yet reliance on aggregate data is likely to mask micro level processes. We note that this implies a stronger test of our thesis since the criticism often is that we simply don't know that individuals being released into counties with social and economic disadvantages are actually reentering into those disadvantaged parts of the county. Indeed, they may be settling into affluent or middle-class communities. But we suspect that is not the case since as we noted previously, a substantial majority of the released population does not have a high school degree and many are functionally illiterate and have, at best, a checkered job history.

We note that offenders leave correctional supervision with a criminal history, a noted source of difficulty in re-entering the community. This study focuses as well on African American median incomes and uses African American Population size as one of the component indicators in the constructed index of concentrated disadvantage. This decision was based on the fact that African Americans make up a substantial proportion of the prison population and represent a socially disenfranchised minority. Social indicators for blacks as a group have been viewed as a plausible proxy for outcomes affecting the most disadvantaged in the U.S. (Wilson, 1987; Rieman, 2008; Costanza, Kilburn, \& Miles, 2013; Costanza, Kilburn, \& Vendetti-Koski, 2013). Future studies should nevertheless expand inquiry to other ethnic and racial minority groups. We note that additional research is certainly warranted and will provide a useful check on the conclusions developed here. With the aforementioned limitations in mind, several research and policy implications can be derived from the study results.

\section{Conclusions}

Correctional institutions across the nation are grappling with ways to reduce the likelihood that offenders who are released to the community will return to prison. While considering recidivism reduction, a recommendation from the crime literature that seems particularly pertinent for reentry policy is placing the focus on non-crime policies (Wilson \& Petersilia, 2011; Kilburn \& Costanza, 2009; Costanza, Kilburn, \& Vendetti-Koski, 2013). In addition to focusing on individualized programming for offenders, if correctional officials want to do something to materially improve prospects for offender reentry, it is crucial they address the non-crime features of offender re-entry. Most of the interferences with successful reentry for offenders are the same things that would put any individual at risk of criminal activity. So attention should focus on reducing the obstacles. In addition to addressing offender needs 
while in prison, programs should systematically address housing, health (including mental health), and safety for released offenders and their family or other social supports.

Correctional education has sometimes been lauded as a remedy for recidivism (Petersilia, 2003; Shrum, 2004). This analysis documents that educational programming is a critical feature of any long term strategy as well as an immediate concern since successful reentry is hampered by the inability of offenders to compete in an increasingly technologically mediated and globalized economy. Important to this theme is not just the indication of a high school degree or its equivalency but involves what is taught in that process. Returning un-credentialed or poorly trained ex-offenders to communities where labor markets are increasingly focused on computer skills matched with abstract thinking and mental production equates with putting offenders back at square one. Offender education should be a top priority and we remind the reader that education is generally state-subsidized throughout the US. That said, in addition to a focus on offender education, boosting educational resources and capacity in the most at-risk communities is a plausible consideration for keeping people out of prison to begin with. In addition to educational concerns it appears that paying attention to the demographics of the areas where inmates are released (Clear, 2009; Petersilia, 2003; Reiman, 2009) as well as targeting employment opportunities can facilitate the transition from prison to community.

When offenders return to a community with little or no resources, they face substantial immediate challenges and their chances for success are limited. In order for the transition from prison to community to be a successful one, a comprehensive array of targeted services is necessary to assist offenders in the reintegration process. Policies targeting investments at schools exhibiting the greatest deficits would undoubtedly reach at-risk youth from which the majority of offenders come. A means tested approach with a progressive scale should be considered so that college is not precluded as an alternative for young adults in the least well-off communities. But such programs would only represent a starting point in reducing recidivism. Visher and Travis (2003, pg. 96) note "The complexities of reestablishing life after prison in the days and weeks after release are many and include the following: finding a place to live; securing formal identification; reestablishing ties with family; returning to high-risk places and situations; and the daunting challenge of finding a job, often with a poor work history and now a criminal record." Kubrin \& Stewart (2006) focus on the dynamics of recidivism and use neighborhood data to predict patterns of re-offending. They note the myriad social problems that inmates confront when released from incarceration and the structural barriers they must overcome.

Some research suggests that investment in long term and low-income housing is an appropriate first step in reducing recidivism. Kilburn \& Costanza (2009) point out problems with community reentry involving access to shelter and food as basic needs that overshadow the importance of resume writing skills. A robust commitment to residential transitional housing in high crime areas is a good starting point for reentry strategies that focus on community based challenges. Likewise a commitment to reinvigoration of labor opportunity in American communities would additionally address root problems of criminal activity in those communities. We note as well that many police departments have faced extensive 
criticism for their aggressive targeting of the poor and people of color in communities throughout the US (Costanza, Helms, Ratansi, Kilburn \& Harmon, 2010). Interventions in the form of community policing and federal monitoring of local imbalances in arrest and charging practices could promote safeguards for minority ex-convicts that reduce the risk that they would be singled out for their minor infractions.

Finally, there is the issue of civil penalties whose consequences seem to have not been well-accounted for in contemporary correctional programming. The list of penalties ex-offenders and their families face is extensive and while some are well known, such as felon disenfranchisement, many others are rarely acknowledged. LaFollette (2005, pp. 241-42) draws attention to an extensive official listing of collateral consequences taking up more than 140 pages. Among the listings: a felon status can affect termination of parental rights, can be a legal basis for divorce, and may result in a permanent ban from holding public office; in many states a convicted felon is barred from all forms of public employment; federal law forbids felons from holding many government jobs or receiving federal contracts; many jurisdictions bar felons from serving on a jury; firearms ownership is banned for felons by federal law, felons are often required to register with local law enforcement; all sex offenders must register with law enforcement for at least 10 years after release from prison and sometimes for longer; sex offenders' names are posted publicly; people convicted of drug felonies can be denied federal assistance, including food stamps. Drug felons and many other felons can be denied federal housing assistance; student loans can be denied based on a simple drug possession conviction; and the list goes on. While such practices are often viewed as part of the "get-tough" justice system, they have the latent effect of handicapping convicted persons in labor markets and retarding their ability to accrue assets while undermining attempts at self-improvement and the development of social capital. In addition to the many commonly identified barriers facing offenders generally (Helms, Gutierrez, \& Reeves-Gutierrez, 2015, 2014), and diverse barriers associated with reentry (housing, employment, health care, mental health, for example), any reasonable and rational reform must address the extensive system of collateral punishments presently targeting convicted felons.

The results of the foregoing analysis reiterate the importance of reentry services and suggest a holistic approach to community reentry. The imperative for new thinking on reentry processes continues to grow in the face of current negative economic developments. Research should seek to build on the findings presented here in order to enhance targeting of programmatic services. Continued empirical research of the links between community contexts and recidivism is warranted as it offers plausible alternatives for reducing the burdens currently facing the United States system of corrections and rehabilitative services (Gutierrez, 2003).

While not every offender confronts an equally adverse environment, the results of this analysis are consistent with claims that many released offenders face difficult challenges. These challenges come in the form of disadvantaged economic and social environments, limited opportunities for meaningful employment and low household incomes that might otherwise provide a source of social and personal support. Many carry with them substantial mental health liabilities as well. Some ex-offenders also come home to a tough law and order 
political environment and must contend with vigilant law enforcement by police in the war on drugs. And so the challenges are varied and state managers of correctional resources would potentially be well advised to be attentive not only to offender responsibility and accountability through direct supervision and other individualized controls, but also to remain aware of the challenges emanating from localized environments.

This type of aggregated analysis cannot speak to individual level decisions, but it offers insight into socially structured patterns and their likely effects on average expectations of success for those returning from incarceration. While it may not be possible to alter the broad social structures that create conditions of disadvantage for at-risk populations, we strongly urge additional research into best practices within corrections, specifically oriented to understanding what efforts are most likely to prepare offenders for release into these very complex environments. Without systematic research and reconsideration of current policies and practices in light of such research, we can only expect to continue to repeat the processes that have taken our society this far along the incarceration pathway.

\section{References}

Aos, S., Miller, M. \& Drake, E. (2006). Evidence-based public policy options to reduce future prison construction, criminal justice costs, and crime rates. Olympia, WA: Washington State Institute for Public Policy.

Bouffard, J. A., MacKenzie, D. L. \& Hickman, L. J. (2000). Effectiveness of vocational education and employment programs for adult offenders: A methodology-based analysis. Journal of Offender Rehabilitation, 31(1-2), 1-41. http://dx.doi.org/10.1300/J076v31n01_01

Callan, V. \& Gardner, J. (2007). The role of VET in recidivism in Australia, in Vocational Education and Training for Adult prisoners and offenders in Australia, Adelaide, Australia: National Centre for Vocational Education Research (Susan Dawe, Ed.), pp. 34-46.

Cecil, D. K., Drapkin, D. A., Mackenzie, D. L. \& Hickman, L. J. (2000). The effectiveness of adult basic education and life-skills programs in reducing recidivism: A review and assessment of the research. Journal of Correctional Education, 207-226.

Chappell, C. (2004). Post-secondary correctional education and recidivism: A meta-analysis of research conducted 1990-1999. Journal of Correctional Education, 5(2), 148-169.

Chiricos, T. G., \& Delone, M. A. (1992). Labor surplus and punishment: A review and assessment of theory and evidence. Social Problems, 421-446. http://dx.doi.org/10.2307/3097019

Costanza, S. E., Kilburn Jr, J. C., \& Vendetti-Koski, S. (2013). Are Minority Areas Disproportionately Targeted for Halfway House Placement? Journal of Ethnicity in Criminal Justice, 11(4), 256-276. http://dx.doi.org/10.1080/15377938.2012.762754

Costanza, S. E., Kilburn, J., \& Miles, B. (2013). The spatial dynamics of legal handgun concealment. Crime Mapping: A Journal of Research and Practice, 5(1), 39-62.

Cullen, F., \& Gendreau, P. (2000). Assessing correctional rehabilitation: Policy, practice, and 
prospects. Policies, Processes, and Decisions in the Criminal Justice System, 3, 109-175. Washington DC: US Department of Justice, Office of Justice Programs.

Day, J. C., \& Newburger, E. C. (2002). The big payoff: Educational attainment and synthetic estimates of work-life earnings. Current Population Reports, Special Studies, 23-210. Retrieved February 16, 2010, from http://www.census.gov/prod/2002pubs/p23-210.pdf

Decker, S. (2007). The relationship between street and prison. Criminology and Public Policy, 6(2), 183-186. http://dx.doi.org/10.1111/j.1745-9133.2007.00428.x

DeHart, D. (2010). Cognitive restructuring through dreams and imagery: Descriptive analysis of a women's prison-based program, Journal of Offender Rehabilitation, 49(1), 23-38. http://dx.doi.org/10.1080/10509670903435449

DeLeon, G., \& Wexler, H. (2009). The therapeutic community for addictions: An evolving knowledge base, Journal of Drug Issues, 39(1), 167-77. http://dx.doi.org/10.1177/002204260903900113

Edenfield, A. (2002). Family Arrested: How to Survive the Incarceration of a Loved One. Albuquerque, American Publishing, Inc.

Farkas, M. F. (2000). Teamwork in the social skills development unit helps adaptively impaired inmates, Corrections Today, 62(7), 118-120.

Farley, H., Murphy, A., \& Bedford, T. (2012). Bridging the digital divide: bringing e-literacy skills to incarcerated students. In Proceedings of the 29th Annual Conference of the Australasian Society for Computers in Learning in Tertiary Education (ASCILITE 2012) (pp. 307-311). Australasian Society for Computers in Learning in Tertiary Education (ASCILITE).

Gaes, G. G. (2008). The Impact of Prison Education Programs on Post-Release Outcomes. Reentry Roundtable on Education.

Gallup-Black, A. (2005). Rural and Urban Trends in Family and Intimate Partner Violence in the United State, 1980-1999 [Computer file]. ICPSR04115-v1. New York City, NY: New York University [producer], 2004. Ann Arbor, MI: Inter-university Consortium for Political and Social Research [distributor], 2005-04-07. http://dx.doi.org/10.3886/ICPSR04115

Greenberg, D. F. (1977). The dynamics of oscillatory punishment processes, The Journal of Criminal Law and Criminology, 68(4), 643-651. http://dx.doi.org/10.2307/1142425

Grommon, E., Davidson II, W. S. \& Bynum, T. S. (2013). A Randomized Trial of a Multimodal Community-Based Prisoner Reentry Program Emphasizing Substance Abuse Treatment. Journal of Offender Rehabilitation, 52(4), 287-309. http://dx.doi.org/10.1080/10509674.2013.782775

Gutierrez, R. S. (2003). Social equity and the funding of community oriented policing. New York: LFB Scholarly publications.

Hallett, M. A. (2002). Race, crime, and forprofit imprisonment Social disorganization as market opportunity. Punishment \& Society, 4(3), 369-393. 
http://dx.doi.org/10.1177/146247402400426798

Haynes, J. (1996). An analysis of recidivism rates for inmates completing vocational/academic programs at Twin Rivers Corrections Center/Edmonds Community College (1984-1995). Journal of Northwest Center for the Study of Correctional Education, $1(1), 43-46$.

Helms, R., \& Costanza, S. E. (2009). Race, politics, and drug law enforcement: an analysis of civil asset forfeiture patterns across US counties. Policing and Society, 19(1), 1-19. http://dx.doi.org/10.1080/10439460802457578

Helms, R. (2009). Modeling the politics of punishment: A conceptual and empirical analysis of 'law in action' in criminal sentencing, Journal of Criminal Justice, 37(1), 10-20. http://dx.doi.org/10.1016/j.jcrimjus.2008.12.004

Helms, R., \& Costanza, S. E. (2010). Modeling the Politics of Punishment: A Contextual Analysis of Racial Disparity in Drug Sentencing, Criminal Justice Review, 35(4), 472-491. http://dx.doi.org/10.1177/0734016810373114

Helms, R., \& Costanza, S. E. (2014). Energy Inequality and Instrumental Violence: An Empirical Test of a Deductive Hypothesis. SAGE Open., 4(2), 1-16. http://dx.doi.org/10.1177/2158244014530730

Helms, R., \& Jacobs, D. (2002). The political context of sentencing: An analysis of community and individual determinants. Social Forces, 81(2), 577-604. http://dx.doi.org/10.1353/sof.2003.0012

Helms, R., Costanza, S. E. \& Johnson, N. (2012). Crouching Tiger or Hidden Dragon: Examining the Discourse on Global Cyber-Terror. Security Journal, 25, 57-75. http://dx.doi.org/10.1057/sj.2011.6

Helms, R., Gutierrez, R. S. \& Reeves-Gutierrez, D. (2014). Public Sector Responses to Jail Mental Health: A Review with Recommendations for Future Research. Sociology Mind, 4(1), 31-35. http://dx.doi.org/10.4236/sm.2014.41004

Helms, R., Gutierrez, R. S. \& Reeves-Gutierrez, D. (2015). Jail Mental Health Resourcing: A Conceptual and Empirical Study of Social Determinants. International Journal of Offender Therapy and Comparative Criminology, pp. 1-28. http://dx.doi.org/10.1177/0306624X15572864

Hesse, M. L. (2009). A snapshot or reentry in Minnesota: Corrections Today, 71(6), 64-67.

Hipp, J. R., Petersilia, J., \& Turner, S. (2010). Parolee recidivism in California: The effect of neighborhood context and social service agency characteristics. Criminology, 48(4), 947-979. http://dx.doi.org/10.1111/j.1745-9125.2010.00209.x

Hogg, R. (2011). Governing Crime at a Distance: Spatiality, Law and Justice. Current Issues in Criminal Justice, 22, 361.

Holzer, H. J., Raphael, S., \& Stoll, M. A. (2004). "Will employers hire former offenders? 
Employer preferences, background checks, and their determinants." In Imprisoning America: The social effects of mass incarceration (Mary Patillo, David Weiman, and Bruce Western, Eds), pp. 210-211. New York: Russell Sage Foundation.

Hubbard, D. (2007). Getting the most out of correctional treatment: Testing the responsivity principle on male and female offenders. Federal Probation, 71(1), 2-8.

Jacobs, D., \& Helms, R. (1996). Towards a political model of incarceration: Ahistorical examination of multiple explanations for prison admission rates, American Journal of Sociology, 102, 323-357. http://dx.doi.org/10.1086/230949

Jancic, M. (1998). Does correctional education have an effect on recidivism? Journal of Correctional Education, 49(4), 152-161.

Jans, N. (2002). Too many convicts. Anchorage, AK: Alaska Northwest Books.

Jonson, C. L., Cullen, F. T., \& Lux, J. L. (2013). Creating Ideological Space: Why public support for rehabilitation matters in Chapter 3 of What Works in Offender Rehabilitation: An Evidence-Based Approach to Assessment and Treatment (Leam Craig, Louise Dixon \& Theresa Gannon, Eds.). http://dx.doi.org/10.1002/9781118320655.ch3

Kassebaum, G., \& Chandler, S. M. (1994). Polydrug use and self control among men and women in prisons, Journal of Drug Education, 24(4), 333-350. http://dx.doi.org/10.2190/YLG8-C7CD-J94Y-XD44

Kelso Jr, C. E. (2000) Recidivism rates for two education programs' graduates compared to overall Washington State rates. Journal of Correctional Education, 51(2), 233-236.

Kilburn, J. C., \& Costanza, S. E (2009). Salvation City: Halfway House Stories. Teneo Press, Amherst, Ma.

Kilburn, J. C., Costanza, S. E., Frailing, K. \& Diaz, S. (2014). A Paper Tiger on Chestnut Lane: The Significance of NIMBY Battles in Decaying Communities. Urbanities: The Journal of the IUAES Commission on Urban Anthropology, 4(2), 4-20

Kubrin, C., \& Stewart, E. (2006). Predicting who reoffends: The neglected role of neighborhood context in recidivism studies. Criminology, 44(1), 165-197. http://dx.doi.org/10.1111/j.1745-9125.2006.00046.x

Kubrin, C., Squires, G., \& Stewart, E. (2007). Neighborhoods, Race, and Recidivism: The Community Reoffending Nexus and its Implications for African Americans. In SAGE Race Relations Abstracts, Vol. 32, pp. 7-37. http://dx.doi.org/10.1177/0307920107073250

LaFollette, H. (2005). Collateral Consequences of Punishment: Civil Penalties Accompanying Formal Punishment. Journal of Applied Philosophy, 22(3), 241-261. http://dx.doi.org/10.1111/j.1468-5930.2005.00308.x

Lambert, E., Hogan, N., Barton, S., \& Stevenson, M. (2007). An evaluation of change, a pilot prison cognitive treatment program. Journal of Articles in Support of the Null Hypothesis, $5(1), 1-17$. 
Land, K. C., McCall, P. L., \& Cohen, L. E. (1990). Structural covariates of homicide rates: Are there any invariances across time and social space? American Journal of Sociology, 95(4), 922-963. http://dx.doi.org/10.1086/229381

Listwan, S. J., Cullen, F. T., \& Latessa, E. J. (2006). How to prevent prisoner re-Entry programs from failing: Insights from evidence based corrections. Federal Probation, 70(3), 19-25.

Lucente, S. W., Fals-Stewart, W., Richards, H. J., \& Goscha, J. (2001). Factor structure and reliability of the revised conflict tactics scales for incarcerated female substance abusers, Journal of Family Violence, 16(4), 437-450. http://dx.doi.org/10.1023/A:1012281027999

Martinson, R. (1974). What Works?-Questions and answers about prison reform. The Public Interest (Spring), pp. 22-54.

Mays, G., \& Ruddell, R. (2008). Making sense of criminal justice: policies and practices. New York, NY: Oxford University Press.

McCarty, H. J. (2006). Educating felons: Reflections on higher education in prison. Radical History Review, 96, 87-94. http://dx.doi.org/10.1215/01636545-2006-005

McSweeney, T., Stevens, A., Hunt, N., \& Turnbull, P. (2007). Twisting arms or a helping hand? Assessing the impact of 'coerced' and comparable 'voluntary' drug treatment options, The British Journal of Criminology, 47(3), 470-490. http://dx.doi.org/10.1093/bjc/azl087

Mears, D., Wang, X., Hay, C., \& Bales, W. (2008). Social ecology and recidivism: Implications for prisoner reentry. Criminology, 46(2), 301-340. http://dx.doi.org/10.1111/j.1745-9125.2008.00111.x

Melnick, G., de Leon, G., Thomas, G., Kressel, D., \& Wexler, H. (2001). Treatment process in prison therapeutic communities: Motivation, participation, and outcome, American Journal of Drug \& Alcohol Abuse, 27(4), 633-650. http://dx.doi.org/10.1081/ADA-100107660

Messemer, J. E. (2003). College programs for inmates: The post-Pell grant era. Journal of Correctional Education, 54(1), 32-39.

Mills, L. (2004). Illinois prisoner reentry: Building a second chance agenda. Annie E. Casey Foundation.

Mitchell, O., \& Harrell, A. (2006). Evaluation of the breaking the cycle demonstration project: Jacksonville, FL and Tacoma, WA, Journal of Drug Issues, 36(1), 97-118. http://dx.doi.org/10.1177/002204260603600105

Myers, S. L., \& Sabol, W. J. (1987). Unemployment and Racial Differences in Imprisonment. The Review of Black Political Economy, 16(1-2), 189-209. http://dx.doi.org/10.1007/BF02900929

Nee, C., \& Farman, S. (2007). Dialectical behaviour therapy as a treatment for borderline personality disorder in prisons: Three illustrative case studies. Journal of Forensic Psychiatry \& Psychology, 18(2), 160-180. http://dx.doi.org/10.1080/14789940601104792 
Nuttall, J., Hollmen, L., \& Staley, E. M. (2003). The effect of earning a GED on recidivism rates. Journal of Correctional Education, 54(3), 90-94.

Parker, K. F., McCall, P., \& Land, K. (1999). Determining social-Structural predictors of homicide: Units of analysis and related methodological concerns. In Homicide: A sourcebook of social Research (M. Dwayne Smith and Margaret A. Zahn, Eds.). pp. 107-124. Thousand Oaks, CA: Sage Publications.

Paternoster, R., Brame, R., Bacon, S., \& Ditchfield, A. (2004). Justice by geography and race: The administration of the death penalty in Maryland, 1978-1999. U. Md. LJ Race, Religion, Gender \& Class, 4, 1.

Petersilia, J. (2003). When prisoners come home: Parole and prisoner reentry. New York, NY: Oxford University Press.

Polaschek, D., Bell, R., Calvert, S., \& Takarangi, M. (2010). Cognitive-behavioural rehabilitation of high-risk violent offenders: Investigating treatment change with explicit and implicit measures of cognition, Applied Cognitive Psychology, 24(3), 437-449. http://dx.doi.org/10.1002/acp.1688

Reiman, J. (2007). The Rich Get Richer and the Poor Get Prison: Ideology, Class and Criminal Justice (8th Ed.). Needham Heights: Allyn \& Bacon.

Rohde, P., Jorgensen, M. A., Seeley, J. R., \& Mace, D. E. (2004). Pilot Evaluation of the Coping Course: A Cognitive-Behavioral Intervention to Enhance Coping Skills in Incarcerated Youth. Journal of the American Academy of Child and Adolescent Psychiatry, 43(6), 669-676. http://dx.doi.org/10.1097/01.chi.0000121068.29744.a5

Sampson, R. J., Raudenbush, S. W., \& Earls, F. (1997). Neighborhoods and violent crime: A multilevel study of collective efficacy. Science, 277(5328), 918-924. http://dx.doi.org/10.1126/science.277.5328.918

Saylor, W. G., \& Gaes, G. G. (2001). The differential effect of industries and vocational training on post-release outcomes for ethnic and racial groups: A Research note, Corrections Management Quarterly, 5(4), 17-24.

Saylor, W., \& Gaes, G. (1997) Training inmates through industrial work participation and vocational and apprenticeship instruction, Corrections Management Quarterly, 1(2), 32-43.

Sayre, G. W. (2006). A lesson plan in cognitive restructuring, Journal of Correctional Education, 57(1), 86-95.

Schnur, A. C. (1948). The educational treatment of prisoners and recidivism. American Journal of Sociology, 54(2), 142-147. http://dx.doi.org/10.1086/220293

Schwarzfeld, M., Weiss, D. M., Plotkin, M., \& Draper, L. (2008). Planning and assessing a law enforcement reentry strategy. New York, NY: Council of State Governments Justice Center.

Seiter, R., \& Kadela, K. (2003). What works, what does not, and what is promising. Crime 
and Delinquency, 49(3), 360-388. http://dx.doi.org/10.1177/0011128703049003002

Shrum, H. (2004). No longer theory: Correctional practices that work. Journal of Correctional Education, 55(3), 225-235.

Stohr, M., Hemmens, C., Shapiro, B., Chambers, B., \& Kelley, L. (2002). Comparing inmate perceptions of two residential substance abuse treatment programs, International Journal of Offender Therapy \& Comparative Criminology, 46(6), 699-714. http://dx.doi.org/10.1177/0306624X02238163

Tewksbury, R., \& Mustaine, E. E. (2006). Where to find sex offenders: An examination of residential locations and neighborhood conditions. Criminal Justice Studies, 19(1), 61-75. http://dx.doi.org/10.1300/J076v31n01_02

Tewksbury, R., Erickson, D. J., \& Taylor, J. M. (2000). Opportunities lost: The consequences of eliminating Pell Grant eligibility for correctional education students. Journal of Offender Rehabilitation, 31(1-2), 43-56.

Tolbert, M., Klein, S., \& Pedroso, R. (2006). Correctional education data guidebook: A working guide for correctional education administrators. MPR and Associates and the U. S. Department of Education.

Travis, J. (2005). But they all come back: Facing the challenges of prisoner reentry. Washington, DC: Urban Institute.

U. S. Department of Justice. (1998). State and federal corrections information systems: An inventory of data elements and an assessment of reporting capabilities. Washington DC: Office of Justice Programs, Bureau of Justice Statistics.

U.S. Dept. of Justice, Bureau of Justice Statistics. NATIONAL CORRECTIONS REPORTING PROGRAM, 2003 [UNITED STATES] [Computer file]. Conducted by U.S. Dept. of Commerce, Bureau of the Census. ICPSR20741-v1. 2007. Ann Arbor, MI: Inter-university Consortium for Political and Social Research [producer and distributor], 2007-09-17. http://dx.doi.org/10.3886/ICPSR20741

Vacca, J. S. (2004). Educated prisoners are less likely to return to prison. The Journal of Correctional Education, 55(4), 297-305.

VanDeCarr, P. (2007). Call to action: How programs in three cities responded to the prisoner reentry crisis. Public Private Ventures.

Vannoy, S. \& Hoyt, W. (2004). Evaluation of an anger therapy intervention for incarcerated adult males. Journal of Offender Rehabilitation, 39(2), 39-57. http://dx.doi.org/10.1300/J076v39n02_03

Visher, C. A., Winterfield, L., \& Coggeshall, M. B. (2005). Ex-offender employment programs and recidivism: A meta-analysis. Journal of Experimental Criminology, 1(3), 295-316. http://dx.doi.org/10.1007/s11292-005-8127-x

Visher, C., \& Travis, J. (2003). Transitions from prison to community: Understanding 
individual pathways. Annual Review of Sociology, 29, 89-113. http://dx.doi.org/10.1146/annurev.soc.29.010202.095931

Visher, C., Lavigne, N. ,\& Travis, J. (2004). Returning home: Understanding the challenges of prisoner reentry, Maryland Pilot Study: Findings from Baltimore. Washington, DC: Urban Institute Justice Policy Center. http://dx.doi.org/10.1037/e720382011-001

Wilson, J. Q., \& Petersilia, J. (2011). Crime and Public Policy. Oxford: Oxford University Press.

Wilson, W. J. (1987). The truly disadvantaged: The inner city, the underclass, and public policy. Chicago: University of Chicago Press.

Zoukis, C. (2012). The Great Escape: Education is the Ticket to Freedom. Retrieved from http://namastehealingcenter.wordpress.com/2012/01/29/the-great-escape-education-is-the-tick et-to-freedom/

\section{Notes}

Note 1 . We note here that the sanctioning regime itself is varied and may include civil as well as criminal penalties. Some research indicates that the actions of police and prosecutors tend toward lenience and favor civil penalties in more affluent areas while defendants targeted in less affluent areas face a heightened risk of being charged criminally (Helms and Costanza 2009).

Note 2. One recommendation that might be productively explored is to emphasize isomorphism between offender supports and environmental complexity in ways that are analogous to what organizations do when seeking to gain predictability in the presence of environmental uncertainty (Thompson 1968; Mintzberg 1979; Oliver 1988). Put differently, organizations seek through internal elaboration to become isomorphic with their environments, to match external and internal complexity.

Note 3. The sample data are taken from an unpublished report (developed by the authors) that sought to compare CDCR release data with two comparison states for purposes of informing the California State Legislature on prisoner reentry problems and prospects. While this data does not include all states, it does include states with substantial variation on key dimensions of interest to this study. We acknowledge its limitations and encourage others to study these important issues using other sample data and methods of inquiry.

Note 4. Our recent personal experience in attempting to gain access to CDCR data on correctional educational and vocational programming for incarcerated offenders does not inspire confidence that the situation in California is any different than the reported experiences of the two comparison states.

Note 5. We note here that not all county units are equal in their historical dependence on manufacturing employment. Having noted this, we emphasize that from a measurement standpoint, these cases would represent low values on the \% change in manufacturing 


\section{Macrothink}

indicator since their 1980 and 1990 values would both be close to 0 . By contrast, areas most negatively impacted by manufacturing losses were generally strongly dependent on these jobs and continue to be so currently. These places would have large values in 1980 and smaller values in 1990, reflecting large negative values in the manufacturing indicator. By contrast, some areas showed substantial counter trends with the country as a whole, which lost manufacturing jobs throughout this period. These areas would show larger 1990 values than in 1980 and so our indicator would record large positive values for these counties.

\section{Copyright Disclaimer}

Copyright for this article is retained by the author(s), with first publication rights granted to the journal.

This is an open-access article distributed under the terms and conditions of the Creative Commons Attribution license (http://creativecommons.org/licenses/by/3.0/). 